\title{
Tradisi Methik Pari dalam bingkai realitas sosial-keagamaan masyarakat tani Dusun Ngadirejo Blitar
}

\author{
Bella Fadhilatus Sanah, Nur Hadi* \\ Universitas Negeri Malang, Jl. Semarang No. 5 Malang, Jawa Timur, Indonesia \\ *Penulis korespondensi, Surel: nur.hadi.fis@um.ac.id
}

Paper received: 01-04-2021; revised: 15-04-2021; accepted: 30-04-2021

\begin{abstract}
Abstrak
Tradisi merupakan salah satu bentuk kebudayaan yang lahir dan melekat di tengah kehidupan masyarakat. Tradisi yang masih hidup di kalangan masyarakat khususnya petani di Pulau Jawa adalah tradisi methik pari. Tradisi tersebut masih dapat dijumpai di Dusun Ngadirejo, Blitar. Tradisi ini kemudian menjadi sebuah realitas sosial keagamaan masyarakat yang sudah ada sejak zaman dahulu. Dalam perkembangan masyarakat digital, tradisi tersebut masih mengakar pada masyarakat. Peneliti menggunakan teori tindakan sosial tradisional Max Weber sebagai pisau analisis pada penelitian ini. Metode yang digunakan adalah pendekatan kualitatif deskriptif. Hasil penelitian menunjukkan bahwa tradisi methik pari telah menjadi kepercayaan dan kebiasaan yang dilaksanakan secara turun temurun oleh masyarakat tani Dusun Ngadirejo. Tradisi methik pari memiliki tujuan untuk mengucap syukur dan memanjatkan doa kepada Tuhan. Doa tersebut berupa ungkapan syukur atas anugerah kekayaan alam dan kelancaran bercocok tanam. Tradisi ini juga dilakukan sebagai wujud kepedulian lingkungan dan penghormatan atas perjuangan para leluhur. Dalam prakteknya, tradisi-tradisi tersebut menerapkan serta mengajarkan nilai-nilai agama pada masyarakat. Oleh karena itu, tradisi methik pari kemudian menjadi sebuah realitas sosial keagamaan dalam kehidupan masyarakat.
\end{abstract}

Kata kunci: tradisi; Methik Pari; tindakan sosial

\section{Pendahuluan}

Kebudayaan merupakan bagian dari suatu entitas masyarakat yang nyata. Menurut Melville J. Herskovits dan Bronislaw Malinowski (dalam Shomad \& Adinata, 2020) mengemukakan bahwa kebudayaan yang dimiliki masyarakat menjadi aspek penentu dalam berbagai hal yang menyangkut kehidupan suatu masyarakat atau yang dikenal dengan Cultural Determinism. Kebudayaan masyarakat Indonesia selalu identik dengan bentuk yang mencirikan kekhasan dan kekayaan daerah. Sebagaimana menurut Shomad (2016) yang menyatakan bahwa budaya adalah segala bentuk sistem pemikiran dan tindakan dari hasil cipta karya manusia yang menjadi milik bersama dan berkembang di masyarakat.

Indonesia sebagai negara multikultural yang kaya dengan keberagaman budaya. Keberagaman budaya tersebut lahir karena berbagai faktor, seperti kondisi geografis, sosial, agama, dan berbagai keyakinan serta kepercayaan masyarakat di suatu daerah. Adanya faktorfaktor itu melahirkan sebuah keberagaman budaya, adat istiadat, bahasa daerah, rumah adat, kesenian, dan tradisi (Kusalanana, et. al., 2020). Kebudayaan turut mencerminkan masyarakatnya. Sebab, nilai yang terkandung dalam suatu kebudayaan merepresentasikan kemajuan peradaban masyarakat yang hidup didalamnya.

Kondisi geografis suatu daerah yang memperkaya khasanah budaya Indonesia ternyata juga memunculkan heterogenitas jenis mata pencaharian masyarakat. Di Indonesia memiliki topografi yang beragam sehingga berakibat pada keberagaman mata pencaharian penduduk 
Indonesia yang mendiami wilayah tertentu. Menengok pada sejarah peradaban bangsa Indonesia, mata pencaharian seperti berburu, meramu, hingga bercocok tanam telah berkembang sejak zaman purba di Indonesia. Bahkan jenis mata pencaharian ini masih bisa dijumpai hingga saat ini, salah satunya adalah bercocok tanam.

Kebutuhan pokok masyarakat Indonesia berupa pangan menjadikan alasan mata pencaharian bercocok tanam masih langgeng hingga kini. Berdasarkan dengan kebutuhan tersebut, nasi menjadi salah satu makan pokok yang banyak digandrungi oleh masyarakat. Sehingga menanam padi menjadi mata pencaharian yang dapat dikategorikan sebagai pekerjaan yang fundamental dalam kelangsungan hidup masyarakat Indonesia. Meskipun di era sekarang luas lahan untuk pertanian kian menyempit, namun tidak mengurangi ketergantungan masyarakat untuk mengkonsumsi nasi sebagai makanan pokok sehari-hari.

Menanam padi di sawah merupakan kebudayaan yang sudah berkembang di masyarakat (Kusalanana, dkk., 2020). Kebudayaan merepresentasikan semua bentuk aktivitas dan tindakan yang dilakukan oleh manusia yang memiliki unsur yang menjadi satu kesatuan. Sebagaimana menurut Koentjaraningrat (1990), menjelaskan bahwa unsur dalam kebudayaan terdiri dari bahasa, sistem pengetahuan, organisasi sosial, sistem peralatan hidup dan teknologi, sistem mata pencaharian, sistem religi dan kesenian. Mata pencaharian menjadi kebudayaan yang berkembang di masyarakat. Unsur kebudayaan yang lahir dari adanya sistem mata pencaharian khususnya bidang pertanian yang ada di Dusun Ngadirejo, Kabupaten Blitar adalah tradisi methik pari.

Tradisi methik pari banyak berkembang di bagian Pulau Jawa khususnya pada masyarakat agraris di pedesaan yang mayoritas bermatapencaharian sebagai petani. Pelaksanaan methik pari pada masyarakat petani Jawa telah ada sejak zaman nenek moyang. Sehingga membuat methik pari menjadi salah satu tradisi yang terus melekat pada masyarakat. Tradisi methik pari dilakukan saat menjelang panen, dimana padi telah tua dan menguning hingga siap untuk dipanen. Tujuan melakukan methik pari adalah untuk memanjatkan syukur kepada yang Kuasa atas limpahan rezeki yang diberikan berupa kelancaran penggarapan sawah dan proses penanaman padi, terhindar dari serangan hama, serta mengharap kelancaranan panen dan hasil panen yang melimpah.

Dalam beberapa grand theory yang diungkapkan oleh tokoh sosiologi menunjukkan adanya sumbangsih dari para teoritisi untuk mengkaji berbagai persoalan yang berkembang di masyarakat. Pada topik permasalahan yang diangkat oleh peneliti ini turut menerapkan teroi besar yang dicetuskan oleh Max Weber untuk menganalisis bentuk tindakan para petani dalam pelaksanaan tradisi methik pari di Dusun Ngadirejo, Kabupaten Blitar.

Max Weber adalah salah satu tokoh sosiologi klasik dengan eksemplar yang dikemukakan olehnya yaitu paradigma definisi sosial, yang defenitif memaparkan bahwa sosiologi menjadi disiplin ilmu yang berusaha menafsirkan serta memahami (interpretative understanding) suatu tindakan sosial individu serta hubungan sosial untuk sampai pada penjelasan sebab akibat (kausal) (UNIQBU, 2019). Tindakan sosial menitikberatkan pada tindakan individu atau pelaku yang kemudian ditujukan kepada orang lain. Tindakan tersebut tidak lepas dari makna, motif tindakan, dan tujuan dari adanya tindakan tersebut. Sebagaimana menurut Muhlis \& Norkholis (2016), teori tindakan sosial Max Weber berorientasi pada motif dan tujuan pelaku. 
Menurut Weber (dalam Jones, 2003), mengatakan bahwa usaha terbaik untuk memahami berbagai kelompok dengan menghargai segala bentuk dan tipikal tindakan yang menjadi ciri khas kelompok tersebut, sehingga dapat interpretative understanding terhadap alasan dan motif masyarakat tersebut bertindak. Weber (dalam Prastowo, 2008) telah membagi lima ciri pokok dalam tindakan sosial dan antar hubungan sosial di masyarakat sebagai berikut:

Pertama, tindakan individu yang menurut aktor mengandung makna yang subjektif. Ini meliputi berbagai tindakan nyata. Dalam hal ini, aktor cenderung mengarahkan tindakan kepada orang lain dengan motif dan tujuan tertentu. Sehingga tindakan yang dilahirkan adalah bersifat subjektif dan nyata. Kedua, tindakan nyata dan yang bersifat membatin sepenuhnya bersifat subjektif. Maksudnya adalah semua tindakan aktor adalah bersifat subjektif, baik itu tindakan yang nyata maupun yang sifatnya membatin.

Ketiga, tindakan memiliki pengaruh positif berdasarkan suatu keadaan yang sengaja diulang serta menunjukkan persetujuan yang sifatnya diam-diam. Tindakan yang dimaksud adalah tindakan yang ditujukan dengan berbagai pertimbangan, baik dari segi pengaruh, kesadaran tujuan, dan persetujuan. Keempat, aktor mengarahkan tindakannya kepada individu atau kelompok lain. Sebab syarat tindakan sosial apabila ditujukan bukan untuk aktor sendiri. Kelima, tindakan aktor adalah memperhatikan, mempertimbangkan, dan tertuju kepada orang lain. Artinya tindakan sosial merupakan representasi atau bentuk tindakan yang tidak lepas dari pengaruh tindakan orang lain, sehingga akan terjadi proses timbal balik dalam bentuk tindakan yang nyata.

Dalam memahami suatu tindakan sosial yang penuh arti, individu harus memperhatikan semua pranata yang terdapat dalam tindakannya sehingga tidak mengabaikan aspek-aspek yang bersifat prinsipil dari kehidupan sosial di masyarakat. Masyarakat sebagai entitas sosial terdapat pula hubungan sosial antar manusia. Hubungan sosial tercermin melalui tujuan dan motif individu yang terlibat dalam hubungan sosial tersebut. Perspektif individu dalam proses hubungan sosial direpresentasikan dalam kemampuannya mengambil manfaat dari suatu tindakan serta memberikan gambaran atas perbedaan makna dari adanya tindakan tersebut.

Weber mengklasifikasikan tipe tindakan sosial berdasarkan konteks motif dan tujuan si aktor, yaitu: tindakan tradisional, tindakan afektif, rasionalitas instrumental dan rasionalitas nilai (Muhlis \& Nurkholis, 2016). Turner (2012) menjabarkan mengenai keempat klasifikasi tersebut, yaitu: Pertama, Tindakan Tradisional, merupakan bentuk tindakan yang telah mengakar secara turun temurun sehingga menjadi kebiasaan. Tipe tindakan tradisional bersifat sakral, sebab mengandung nilai-nilai budaya yang secara sadar diterapkan dalam kehidupan sehari-hari yang pada prakteknya melahirkan suatu kebiasaan yang mengakar di masyarakat.

Kedua, Tindakan Afektif, merupakan tindakan yang ditentukan oleh kondisi serta orientasi emosional si aktor. Tipe ini menunjukkan adanya intervensi dari perasaan aktor atau pelaku yang mendasari atau menjadi motif dari tindakan yang dilakukan oleh aktor. Pada umumnya, tindakan ini lebih menekankan pada kondisi khusus emosional aktor. Ketiga, Rasionalitas Instrumental, adalah tindakan yang bertujuan untuk mencapai tujuan yang telah dipikirkan secara rasional melalui upaya dan perhitungan aktor yang bersangkutan. Maksudnya bahwa suatu tindakan dapat bersifat rasional apabila dalam pelaksanaannya 
mempertimbangkan berbagai kemungkinan dalam rangka untuk mencapai tujuan yang diinginkan dari adanya tindakan tersebut.

Keempat, Rasionalitas Nilai, yaitu tindakan rasional berdasarkan nilai, yang ditentukan oleh nilai yang dipercaya serta diyakini secara personal dalam mencapai tujuan atau alasan tertentu namun tanpa mempertimbangkan prospek berhasil atau gagalnya tindakan yang dilakukan aktor. Dapat diartikan bahwa aktor atau pelaku tindakan tidak menitikberatkan pada keberhasilan dari tindakan yang dilakukan. Oleh karena itu, tindakan rasionalitas nilai memfokuskan pada apa yang hendak dilakukan dan mengesampingkan akibat dari tindakan tersebut.

Klasifikasi empat tipe tindakan sosial tersebut mengindikasikan sifat-sifat tertentu dari individu yang dapat diamati dari tindakan yang dilakukan. Tindakan sosial yang dilakukan oleh aktor sangat berkaitan dengan kondisi perasaan (faktor internal) yang kemudian dimanifestasikan kepada orang lain dengan orientasi tertentu. Dari keempat tipe tindakan sosial yang telah dijabarkan, pada penelitian ini akan menggunakan tipe tindakan sosial tradisional untuk menganalisis eksistensi tradisi methik pari di Dusun Ngadirejo Kabupaten Blitar yang tetap mengakar di masyarakat. Tujuan menggunakan teori tipe tindakan sosial tradisional pada penelitian ini adalah untuk memahami tujuan serta motif dari aktor atau pelaku tradisi methik pari yang hingga kini masih menjaga dan melestarikan tradisi tersebut.

\section{Metode}

Metode yang digunakan dalam penelitian ini adalah metode penelitian kualitatif. Metode penelitian kualitatif adalah metode penelitian yang diterapkan untuk meneliti kondisi objek yang sifatnya alamiah, (sebagai lawan dari eksperimen) yang menempatkan peneliti sebagai instrumen kunci (Kusalanana, et. al., 2020). Pendekatan yang digunakan adalah pendekatan kualitatif deskriptif. Alasan menggunakan pendekatan tersebut sebab terdapat keunikan tersendiri dari tradisi methik pari di Dusun Ngadirejo Kabupaten Blitar ini. Sehingga peneliti akan mudah untuk menganalisis fenomena sosial yang terjadi pada petani Dusun Ngadirejo selama melaksanakan tradisi tersebut.

Penelitian ini berlokasi di Dusun Ngadirejo, Desa Genengan, Kecamatan Doko, Kabupaten Blitar. Lokasi tersebut layak diteliti karena di Dusun Ngadirejo peneliti menemukan pelaksanaan tradisi methik pari. Dalam penelitian kualitatif, peneliti berperan sebagai instrumen utama sehingga harus divalidasi pemahaman serta kesiapan dalam menerapkan penelitian kualitatif saat melakukan riset di lapangan (Sugiyono, 2016). Informan penelitian ditentukan dengan teknik purposive, yaitu memilih informan berdasarkan kriteria tertentu (Saleh, et. al., 2014). Teknik ini digunakan dengan mempertimbangkan beberapa kriteria, salah satunya yaitu informan yang memahami tentang tradisi methik pari secara mendalam. Sehingga data yang didapatkan lebih detail dan bersifat kredibel.

Adapun informan atau narasumber yang dipilih adalah sesepuh dusun, tokoh agama, tokoh masyarakat, dan beberapa petani yang melaksanakan tradisi methik pari di Dusun Ngadirejo. Teknik pengumpulan data dilakukan melalui wawancara, observasi, dan dokumentasi. Penggunaan teknik tersebut dalam pengumpulan data akan memudahkan peneliti khususnya dalam penelitian kualitatif. Salah satu sumber informasi penelitian kualitatif yang penting adalah didapatkan melalui wawancara. Wawancara adalah suatu proses interaksi antara pewawancara dengan narasumber (Husin, 2019). 
Wawancara merupakan percakapan yang dilakukan dengan mengajukan pertanyaan kepada informan atau narasumber dalam penelitian untuk dijawab guna mendapatkan data yang diperlukan. Hal tersebut sebagaimana pengertian wawancara menurut Esterberg (2002) yang mengatakan bahwa wawancara atau interview merupakan interaksi yang melibatkan dua orang untuk saling bertukar informasi melalui tanya jawab, sehingga makna dapat dikonstruksikan ke dalam suatu topik yang ditentukan. Teknik tersebut digunakan untuk mendapatkan data terkait tradisi methik pari yang diperlukan dengan bertanya langsung kepada informan penelitian. Sehingga melalui teknik tersebut, dapat diinterpretasikan segala fenomena yang tidak secara langsung diketahui oleh peneliti selama penelitian berlangsung.

Sebagaimana menurut Susan Stainback dan William Stainback (1988) melalui wawancara peneliti dapat mengetahui berbagai hal dengan lebih mendalam dan menafsirkan keadaan atau kondisi serta fenomena yang terjadi, yang tidak diperoleh melalui observasi. Observasi merupakan kegiatan untuk mempelajari tentang perilaku serta makna atau motif dari perilaku tersebut (Marshall, 1995). Tujuan dari menggunakan teknik observasi adalah untuk memperoleh kelengkapan data penelitian. Selain itu, data yang didapatkan akan lebih tajam khususnya dalam memahami makna setiap perilaku yang diamati. Teknik observasi ditujukan guna mendapat data proses pelaksanaan tradisi methik pari yang dilaksanakan oleh petani Dusun Ngadirejo dari awal mulainya tradisi hingga selesai untuk memahami tentang tingkah laku informan atau narasumber secara langsung dalam melaksanakan prosesi tradisi.

Dokumentasi merupakan teknik analisis terhadap tulisan atau isi dari suatu dokumen. Menurut Bungin (2012), teknik dokumentasi diterapkan dalam penelitian sosial guna mendapatkan serta data dari sumber bukan manusia untuk menelusuri data historis. Analisis data penelitian kualitatif difokuskan ketika turun lapangan saat mencari pengumpulan data (Sugiyono, 2016). Teknik analisis data yang diterapkan adalah teknik triangulasi dengan tujuan menguji kredibilitas data hasil temuan lapangan. Triangulasi adalah teknik pemeriksaan keabsahan data yang memanfaatkan sesuatu yang lain (Moleong, 2007). Triangulasi dilakukan dengan melakukan wawancara kepada tokoh masyarakat guna mengetahui kredibilitas data yang telah diperoleh peneliti.

Triangulasi atau gabungan, yaitu analisis data bersifat induktif dan hasil dari penelitian kualitatif lebih menekankan makna daripada generalisasi (Sugiyono, 2013). Triangulasi pada tahap kredibilitas data suatu penelitian dengan membandingkan berbagai sumber serta menggunakan berbagai cara yang tepat. Setelah data diuji kredibilitasnya melalui triangulasi, maka tahap selanjutnya adalah menguji validitasnya. Teknik analisis data dilakukan dengan melalui beberapa tahapan sebagaimana dijelaskan oleh Miles dan Huberman (dalam Dalmenda \& Elian, 2017) sebagai berikut.

Pertama, reduksi data yaitu mengurangi dan membuang data pada transkrip wawancara yang tidak relevan atau tidak diperlukan . Kedua, data yang sudah melalui tahap reduksi data selanjutnya diproses pada tahap penyajian data. Tahap display data diterapkan dengan menyajikan data dalam beragam bentuk untuk memudahkan dalam menginterpretasikan kondisi yang terjadi guna merencanakan kerja pada tahap selanjutnya. Ketiga, pengambilan keputusan dan verifikasi yaitu menyimpulkan dan mengecek ulang data-data yang telah direduksi dan disajikan. Ketiga tahapan tersebut berlangsung dalam waktu bersamaan dengan proses yang berkelanjutan. 


\section{Hasil dan Pembahasan}

Sektor pertanian menjadi kekuatan bagi ketahanan pangan di Indonesia. Para petani, khususnya di Pulau Jawa memiliki cara yang unik dalam pelaksanaan kegiatan budidaya di sektor pertanian. Hal tersebut terepresentasi dalam bentuk tradisi. Tradisi yang masih berkembang di masyarakat tani Dusun Ngadirejo, Desa Genengan, Kecamatan Doko, Kabupaten Blitar adalah tradisi methik pari. Terdapat makna yang mendalam dari pelaksanaan tradisi tersebut. Tradisi yang diadakan secara turun temurun sejak zaman sesepuh hingga saat ini masih tetap dilestarikan sebagai wujud kepedulian serta penghormatan pada para leluhur masyarakat tani Dusun Ngadirejo, Kabupaten Blitar.

Adanya pelaksanaan tradisi tersebut menunjukkan adanya upaya pelestarian budaya serta nilai dan norma yang ada di masyarakat. Menurut Sukatman (2002), tradisi yang ada di masyarakat dapat pula berfungsi sebagai perbaikan aspek fisik, aspek ekonomi dan mampu mengenali dan memanfaatkan potensi lingkungan (sejarah, makna, keunikan lokasi dan citra tempat). Hal ini menunjukkan peran suatu tradisi yang mendukung keberlangsungan hidup manusia melalui penerapan nilai dan norma yang mengatur kehidupan suatu masyarakat.

\subsection{Gambaran Umum Masyarakat Desa Genengan}

Desa Genengan memiliki kondisi geografis yang cocok untuk bercocok tanam berbagai tanaman. Dari data Badan Statistik Desa, Desa Genengan memiliki wilayah seluas 355,25 hektar. Luas tersebut didominasi dengan sawah yang luasnya mencapai 152,81 hektar. Luas tanah di wilayah Desa Genengan juga terdiri atas ladang/tegalan 131,00 hektar, pemukiman 26 hektar, dan pekarangan 10 hektar. Luas tanah Desa Genengan juga meliputi tanah untuk fasilitas umum, seperti tanah bengkok 12,70 hektar, tanah titi soro 1,60 hektar, luas perkantoran 0.06 hektar, tanah pemakaman 1,08 hektar, dan luas jalan 20.00 hektar. Kondisi demografis Desa Genengan memiliki jumlah penduduk seluruhnya sebanyak 2.568 orang dengan usia produktif sebanyak 2.106 orang (usia 15-65 tahun) yang memiliki pekerjaan disajikan pada Tabel 1.

Tabel 1. Mata Pencaharian Penduduk Desa Genengan

\begin{tabular}{ll}
\hline Mata Pencaharian & Jumlah \\
\hline PNS & 26 \\
Pedagang & 77 \\
Petani/Pekebun & 388 \\
Peternak & 5 \\
Karyawan Swasta & 165 \\
Buruh Tani/Perkebunan & 259 \\
Perangkat Desa & 5 \\
Wiraswasta & 240 \\
\hline
\end{tabular}

Sumber : (BPS Desa Genengan Tahun, 2020)

Berdasarkan data di atas menunjukkan bahwa luas tanah yang ada di Desa Genengan didominasi dengan luas lahan pertanian. Sehingga tidak asing apabila sebagian masyarakat memiliki mata pencaharian sebagai petani. Oleh karena itu, mata pencaharian petani masih banyak dijumpai pada masyarakat Dusun Ngadirejo, Desa Genengan, Kecamatan Doko, Kabupaten Blitar. Hasil pertanian di Desa Genengan cukup melimpah, setidaknya mencapai 150 ton untuk tiap kali panen. Hasil panen berupa padi dan jagung. 


\subsection{Tradisi Methik Pari}

Tradisi methik pari merupakan bentuk upaya pelestarian kebudayaan yang dimotori oleh para petani di Dusun Ngadirejo, Desa Genengan, Kecamatan Doko, Kabupaten Blitar. Pelestarian kebudayaan dalam bentuk tradisi ini lebih dikenal oleh masyarakat dengan sebutan nguri-nguri budhaya Jawa. Pasalnya, tradisi yang telah ada sejak zaman leluhur ini masih tetap ada bahkan masih menjadi tradisi yang diagungkan oleh para petani. Berdasarkan pemaparan dari informan, tradisi methik pari selain sebagai bentuk upaya nguri-nguri budhaya Jawa juga digunakan sebagai sarana berdoa kepad Sang Pencipta.

Tradisi methik pari merupakan bentuk tradisi sedekah bumi yang dilakukan dalam rangka mengucap syukur atas rezeki yang diberikan oleh Tuhan Yang Maha Kuasa berupa padi yang melimpah ruah. Luas sawah yang membentang dari tiap petak berisi padi kuning yang siap panen. Tradisi ini dilaksanakan sebelum menjelang panen padi. Berdasarkan hasil wawancara dengan narasumber, para petani mempercayai bahwa kegiatan yang dilakukan selama budidaya padi perlu disyukuri. Mulai dari kegiatan menanam padi, panen padi, hingga padi yang terhindar dari serangan hama. Tradisi methik pari juga menjadi sarana berdoa untuk meminta kelancaran panen serta meminta hasil panen yang melimpah.

Dari data hasil observasi yang dilakukan oleh peneliti, prosesi pelaksanaan tradisi methik pari dilakukan di bagian sudut atau pojok sawah. Proses ini diawali dengan meletakkan sesaji di bagian pojok sawah milik petani. Sesaji yang diletakkan ini memiliki makna sebagai bentuk menghormati arwah para leluhur. Setelah itu, petani memanjatkan doa kepada Tuhan Yang Maha Esa sebagaimana agama atau kepercayaan yang dianutnya. Dalam pelaksanaan ritual membaca doa, petani biasanya mengundang tokoh agama yang dipercaya di lingkungan sekitar untuk memanjatkan doa saat methik pari. hal ini dilakukan agar doa yang dipanjatkan dapat tersampaikan kepada Tuhan Yang Maha Esa.

Berdasarkan pernyataan narasumber, doa yang mengudara dari hati para petani sebagai bentuk ungkapan syukur yang tiada batasnya sebagaimana luas angkasa yang diciptakan oleh Tuhan. Sebab, bertani dan bercocok tanam menjadi sumber kehidupan utama bagi masyarakat Dusun Ngadirejo yang mayoritas memiliki mata pencaharian sebagai petani. Dalam pelaksanaan tradisi yang banyak dikenal dengan sedekah bumi ini dilakukan dengan kegiatan genduren atau kenduri di sawah. Dalam kenduri ini, petani ini membawa makanan untuk dapat dibagikan kepada petani atau orang yang datang mengikuti serangkaian prosesi tradisi ini.

Setelah pelaksanaan ritual methik pari, nasi, ayam ingkung (ayam kampung), dan lauk pauk lain dibagi sejumlah orang yang ada. Hal itu dilakukan karena sudah menjadi adat masyarakat bahwa setiap orang yang ada harus mendapatkan makanan dari kegiatan kenduri ini. Kenduri menjadi bagian terpenting dalam rangkaian prosesi methik pari. Kenduri yang dilakukan dalam rangkaian kegiatan sedekah bumi juga menjadi sarana untuk meminta berkah. Oleh karena itu, makanan yang diperoleh dari kenduri bersama saat methik pari disebut dengan "berkat" yang berarti berkah atau barokah.

Melalui tradisi methik pari menunjukkan lestarinya kearifan lokal masyarakat petani di Pulau Jawa, khususnya di Dusun Ngadirejo, Kabupaten Blitar. Dari ritual tradisi yang dilakukan dapat dilihat bahwa setiap tindakan yang dilakukan merepresentasikan motif dan tujuan yang hendak dicapai. Tindakan yang dilakukan oleh para petani berupa perbuatan yang bagi 
pelakunya memiliki makna subjektif. Makna subjektif yang dimaksudkan sebagaimana menurut Weber yaitu keinginan untuk mencapai tujuan dengan motif tindakan tertentu.

Tindakan yang dilakukan oleh pelaku akan menjadi sosial apabila tindakan tersebut tidak sebatas untuk diri sendiri, tetapi juga diarahkan kepada orang lain. Tindakan sosial yang dilakukan memiliki maksud subjektif yang membuat idividu memikirkan setiap tindakan yang dilakukan serta menunjukkan ciri khas tingkah laku yang bermakna bagi individu atau kelompokm lainnya. Dalam perspektif Weber pelestarian tradisi methik pari yang ditemui peneliti di Dusun Ngadirejo, Desa Genengan merupakan bagian dari transfer ilmu dan pemahaman terkait suatu tradisi dengan tindakan sosial melalui cara-cara yang dapat diterima oleh masyarakat.

Pandangan Weber tentang tindakan sosial tidak terletak pada substansi dari suatu tindakan, melainkan bentuk subjektivitas tindakan individu. Berdasarkan empat klasifikasi tindakan sosial menurut Max Weber, tradisi methik pari adalah salah satu bentuk tindakan yang dikategorikan sebagai tindakan sosial tradisional. Tradisi ini dilaksanakan atas dorongan atau motivasi pada tradisi-tradisi yang sudah ada sejak zaman lampau hingga saat ini. Tindakan ini dilakukan dengan berpedoman pada nilai-nilai luhur adat istiadat dan kebiasaan pada masa lampau yang tertuang dalam tradisi methik pari. Adat istiadat leluhur dilaksanakan secara ajeg yang dituangkan dalam bentuk tradisi methik pari.

Pada umumnya, perkembangan tradisi semacam ini dalam masyarakat selalu berpegang pada hukum-hukum yang bersifat lazim di masyarakat. Tindakan sosial tradisional yang ada dalam bentuk tradisi methik pari mempunyai motif dan tujuan yang jelas. Sehingga segala hal yang dipergunakan dalam tercapainya tujuan tersebut juga memiliki makna yang jelas. Ritual yang dilaksanakan dalam kedua tradisi ini juga merupakan tindakan sosial. Sebab, tindakannya jelas dan nyata diarahkan kepada orang lain. Selain itu, tindakan yang dilakukan ini juga bersifat membatin dan subjektif yang terjadi akibat adanya pengaruh postif dan secara sengaja diulang karena situasi dan keadaan tertentu.

Dalam prakteknya, tradisi methik pari dilaksanakan sebagaimana agama atau keyakinan individu yang melaksanakan. Kunci utama dalam melaksanakan sebuah tradisi yang merupakan hasil kebudayaan masyarakat adalah tidak menyimpang dari nilai dan norma yang berlaku di masyarakat itu sendiri. Sehingga terdapat beberapa nilai ajaran keagamaan tertuang dalam tradisi tersebut. Melalui tradisi methik pari menunjukkan adanya intervensi agama dalam kehidupan sosial masyarakat. Bahkan agama memiliki hegemoni dalam bentuk tradisi yang sudah ada sejak zaman nenek moyang dan diwariskan secara turun temurun. Nilai-nilai agama tersebut mengakar dalam aktivitas sosial masyarakat. Sehingga tradisi tersebut kemudian menjadi sebuah realitas sosial keagamaan masyarakat tani Dusun Ngadirejo, Kabupaten Blitar.

Nilai-nilai serta ajaran agama dalam pelaksanann ritual methik pari di sawah nampak pada saat memberikan sesajen seraya memanjatkan doa. Ajaran agama yang didapatkan adalah mendekatkan diri serta memasrahkan segala urusan duniawi kepada Tuhan. Sebab, kepercayaan masyarakat bahwa Tuhan adalah yang mengatur segala kejadian di Bumi, termasuk yang mengendalikan sektor pertanian sebagai sumber kehidupan petani. Dalam pandangan Emile Durkheim mengenai nilai-nilai yang terkandung dalam sistem kepercayaan berkaitan dengan hal-hal yang bersifat sakral. Komunitas atau kelompok masyarakat yang mengedepankan unsur tradisi bersamaan dengan ritual tidak lepas dari praktek-praktek 
keagamaan. Sebagaimana dalam pelaksanaan methik pari, petani melakukan doa pada pojok atau sudut sawah dengan meletakkan sesajen. Agama menjadi ajaran dan pedoman yang dipegang teguh oleh para pemeluknya. Sehingga semua kebiasaan yang kemudian menjadi budaya secara lazim menginterpretasikan kepatuhan beragama di kalangan petani.

Praktek sosial keagamaan dalam tradisi methik pari lekat dengan simbol dan makna yang kompleks. Setiap item dan perlengkapan yang digunakan atau dibawa petani saat methik pari merepresentasikan bentuk orisinil dari suatu tradisi. Melalui implementasi ajaran agama dalam tradisi ini, dapat meningkatkan kesadaran kolektif berkaitan dengan pembentukan solidaritas dan integrasi sosial di masyarakat yang disatukan oleh persamaan keyakinan atau kepercayaan (agama). Sehingga kesadaran atas identitas yang sama menjadi substansi beragama dalam pelaksanaan tradisi methik pari.

Oleh karena itu, realitas semacam ini (tradisi methik pari) telah menjadi bentuk kebiasaan dalam struktur sosial masyarakat Dusun Ngadirejo. Tradisi ini menjadi warisan nenek moyang yang dipercayai oleh masyarakat memiliki nilai-nilai historis dengan ajaran keagamaan serta unsur-unsur magis yang lekat. Pelestarian tradisi dari generasi ke genarasi menjadikannya tidak terlepas dari tindakan yang bersifat sakral dan penuh makna (membatin) sebagai warisan para leluhur yang diyakini dan dipercaya oleh para petani. Max Weber menyebut hal ini dengan tindakan sosial tradisional (traditional action) yang mana tindakan tersebut didasarkan pada nilai-nilai tradisi dan kebiasan yang dilakukan secara turun temurun sejak zaman nenek moyang mereka.

\section{Simpulan}

Tradisi methik pari merupakan tradisi masyarakat petani Jawa yang sudah dilakukan sejak zaman nenek moyang dan keberadaannya sudah lama hidup dalam jantung masyarakat. Meski demikian, tradisi ini masih tetap menunjukkan eksistensinya di era masyarakat digital saat ini. Kelestarian tradisi ini masih tetap dijaga oleh masyarakat. Ritual dalam tradisi methik pari yang hingga kini masih lestari di kalangan masyarakat tani Dusun Ngadirejo, Desa Genengan, Kecamatan Doko, Kabupaten Blitar. Tradisi-tradisi tersebut merupakan tradisi yang telah diwariskan oleh para pendahulu yang tetap bertahan di tengah gerusan arus globalisasi dan modernisasi. Meskipun dalam hal bercocok tanam, para petani Dusun Ngadirejo telah menerapkan berbagai upaya modernisasi, seperti penggunaan traktor untuk membajak sawah.

Akan tetapi hal tersebut tidak membuat para petani melupakan semua tradisi dari leluhur mereka. Hal ini dapat terwujud karena kesadaran masyarakat untuk melestarikan tradisi-tradisi tersebut. Aksi para petani dalam melakukan ritual methik pari menjadi salah satu dari bentuk tindakan sosial karena ditujukan pada orang lain. Pandangan para petani Dusun Ngadirejo terhadap tradisi methik pari dianggap sebagai sarana untuk berdoa kepada Tuhan Yang Maha Esa untuk meminta rezeki yang melimpah. Selain itu, juga sebagai sarana untuk mengucap syukur atas kekayaan alam dan hasil panen yang dikaruniakan Tuhan.

Dalam pelaksanaan tradisi ini juga sebagai wujud kepedulian sosial antar petani karena menunjukkan aksi solidaritas dalam kegiatan bersama. Melalui kirim doa menjadi bentuk penghormatan pada para pendahulu mereka. Hal ini turut merepresentasikan kesadaran petani untuk menjaga kelestarian lingkungan yang menjadi sumber penghidupan mereka. Dalam prakteknya tradisi methik pari juga mengajarkan nilai-nilai keagamaan kepada masyarakat dengan menghaturkan doa untuk keselamatan dan keberkahan dalam bercocok tanam di sektor pertanian. 


\section{Daftar Rujukan}

BPS Desa Genengan. (2020). Data Mata Pencaharian Penduduk Desa Genengan.

Bungin, B. (2012). Analisis Penelitian Kualitatif. Jakarta: PT. Rajagrafindo Persada.

Dalmeda, M. A., \& Elian, N. (2017). Makna Tradisi Tabuik Oleh Masyarakat Kota Pariaman (Studi Deskriptif Interaksionisme Simbolik). Jurnal Antropologi: Isu-Isu Sosial Budaya, 18(2), 135-150.

Esterberg, K. G. (2002). Qualitative Methods in Social Research. New York: Mc Graw Hill.

Husin, M. (2019). Analisis Urf Terhadap Tradisi Larangan Perkawinan Ngalor Ngulon di Desa Madusari Kecamatan Siman Kabupaten Ponorogo (Doctoral dissertation, IAIN Ponorogo).

Jones, P. (2003). Pengantar Teori-Teori Social: Dari Teori Fungsionalisme Hingga Post Modernisme, (trj.) Saifuddin. Jakarta: Pustaka Obor.

Koentjaraningrat, R. M. (1990). Sejarah Teori Antropologi. Jilid 1. Jakarta: UI Press.

Dewi, M. P. (2020). Makna simbolik ritual Selamatan Methik Pari dalam pandangan agama Buddha di Desa Gembongan Kecamatan Ponggok Kabupaten Blitar. SABBHATA YATRA: Jurnal Pariwisata dan Budaya, 1(1), 32-44.

Marshall, C., \& Rossman, G. B. (2014). Designing qualitative research. Sage publications.

Moleong, L. J. (2007). Metodologi Penelitian Kualitatif. Bandung (ID): Remaja Rosdakarya.

Muhlis, A., \& Norkholis, N. (2016). Analisis Tindakan Sosial Max Weber dalam Tradisi Pembacaan Kitab Mukhtashar Al-bukhari (Studi Living Hadis). Jurnal Living Hadis, 1(2), 242-258.

Prastowo, R. (2008). Karakteristik Sosial Ekonomi dan Perilaku Kerja Perempuan Pedagang Asongan. Skripsi Universitas Sebelas Maret.

Saleh, H. D., Rokhmah, D., \& Nafikadini, I. (2014). Fenomena Penyalahgunaan NAPZA Di Kalangan Remaja Ditinjau Dari Teori Interaksionisme Simbolik Di Kabupaten Jember (The Phenomenon of Substance Abuse among Adolescents Based on Symbolic Interactionism Theory in Jember Regency). Pustaka Kesehatan, 2(3), 468-475.

Shomad, A. (2016). Studi Semiotika Perang Bangkat: Era Tradisional Dan Era Modernisasi. HISTORIA: Jurnal Program Studi Pendidikan Sejarah, 4(2), 103-118.

Shomad, A., \& Adinata, T. P. (2020). Tradisi Adat Methik Pari Di Desa Kalistail Kecamatan Genteng Kabupaten Banyuwangi (Studi Pendekatan Historis). AGASTYA: JURNAL SEJARAH DAN PEMBELAJARANNYA, 10(1), $35-47$.

Stainback, S., \& Stainback, W. (1988). Understanding \& Conducting Qualitative Research. Council for Exceptional Children, Publication Sales, 1920 Association Dr., Reston, VA.

Sugiyono, S. (2013). Memahami Penelitian Kualitatif. Bandung: Alfabeta.

Sugiyono, S. (2016). Metode Penelitian Kuantitatif, Kualitatif, dan R\&D. Bandung: Alfabeta.

Sukatman, S. (2002). Butir- Butir Tradisi Lisan. Yogyakarta: Tim Laks Bang.

Turner, B. S. (2012). Relasi Agama dan Teori Sosial Kontemporer. Edisi baru. Cet. I. Yogyakarta: IRCiSoD.

Turner, B. S. (2012). Teori Sosial Dari Klasik Sampai Postmodern. Yogyakarta: Pustaka Pelajar.

UNIQBU, PSP2M. (2019). Tindakan Sosial. 